\title{
Effects of ex vivo ischemia time and delayed processing on quality of specimens in tissue biobank
}

\author{
DAN GUO $^{1 *}$, ANQI WANG $^{1 *}$, TING XIE $^{1 *}$, SUMEI ZHANG $^{1}$, DINGYAN CAO $^{1}$ and JIAN SUN ${ }^{1,2}$ \\ ${ }^{1}$ Clinical Biobank, Department of Medical Research Center; ${ }^{2}$ Department of Pathology, Peking Union Medical \\ College Hospital, Chinese Academy of Medical Sciences and Peking Union Medical College, Beijing 100730, P.R. China
}

Received January 14, 2020; Accepted July 16, 2020

DOI: $10.3892 / \mathrm{mmr} .2020 .11503$

\begin{abstract}
The RNA quality of tissue biobank is crucial for translational research; however, the effects of the ex vivo ischemia time on RNA integrity and expression of genes related to hypoxia, stress, apoptosis and autophagy remains elusive. A total of 18 carcinoma tissues were stored at room temperature for $15 \mathrm{~min}, 30 \mathrm{~min}, 1,2,4,8$ and $24 \mathrm{~h}$. The integrity and purity of isolated RNA were analyzed. Furthermore, the gene expression of mTOR, hypoxia-inducible factor $1 \alpha$, phosphatidylinositol 4,5-bisphosphate 3-kinase catalytic subunit $\beta$ isoform (PI3KCB), threonine kinase 1 (AKT1), NF- $\kappa$ B, protein kinase AMP-activated catalytic subunit $\alpha 1$ (AMPK $\alpha 1$ ), caspase 8 (CASP8), unc-51 like autophagy activating kinase 1 and Fas cell surface death receptor were analyzed using reverse transcription-quantitative PCR. The results demonstrated that RNA integrity numbers (RINs) remained stable in carcinoma tissues following ex vivo ischemia for $2 \mathrm{~h}$ at room temperature and that degradation began at $4 \mathrm{~h}(\mathrm{P}<0.001)$. Additionally, the expression of PI3KCB, AKT1, AMPK $\alpha 1$ and CASP8 decreased at time points $8-24 \mathrm{~h}$ following ex vivo ischemia and delayed processing $(\mathrm{P}<0.001)$. In conclusion, $>2 \mathrm{~h}$ of ex vivo ischemia and delayed processing induced RNA degradation and a decrease in RIN, and the gene expressions of PI3KCB, AKT1, AMPK $\alpha 1$ and CASP8 may be considered as markers to evaluate tissue quality at the gene expression level, providing a method for the standard processing and assessment of tissue specimen.
\end{abstract}

Correspondence to: Professor Jian Sun, Clinical Biobank, Department of Medical Research Center, Peking Union Medical College Hospital, Chinese Academy of Medical Sciences and Peking Union Medical College, 1 Shuaifuyuan, Dongdan Road, Dongcheng, Beijing 100730, P.R. China

E-mail: sunjian0720@126.com

${ }^{*}$ Contributed equally

Key words: ex vivo ischemia time, delayed processing time, tissue biobank, pre-analysis variable, RNA integrity number

\section{Introduction}

Tissue biobanks support the collection, analysis, storage and distribution of biospecimens for basic, translational and clinical research. With the advent of proteomics, transcriptomics and metabolomics, as well as the development of bioinformatics, molecular imaging and drug discovery, the demand for high-quality tissue biospecimens continues to increase $(1,2)$, large-scale and high-flux research requirements for high quantity and quality biospecimens have allowed tissue biobanks to develop from undeveloped, small-scale storages to complex and multifaceted large-scale storages (3).

Quality assurance and quality control are critical for tissue biobanks to ensure that biospecimens distributed to researchers are comparable and produce accurate results; as a rough estimate, the number of stored tissue biospecimens was $>300$ million in the US around 2000 , with this number increasing at the rate of 20 million/year (4). However, according to a survey taken by $>700$ cancer researchers, $47 \%$ of them were of the opinion that sample quality is difficult to control and $60 \%$ questioned the quality of samples (4).

There are various factors influencing the quality of biospecimens, and pre-analytical variables are crucial $(5,6)$. Pre-analytical variables are divided into the pre-acquisition and post-acquisition phases. In the pre-acquisition phase, factors such as anesthesia $(7)$, surgical trauma $(8,9)$ and in vivo ischemia (10) might affect the cell integrity and gene expression profiles of the biospecimen, but they cannot be controlled very well because of the uncertainty of clinical treat requirements (11). Rather, factors such as ex vivo ischemia time, delayed processing time and processing temperature, which are crucial for bio-specimen quality (12), can be controlled and standardized effectively.

To the best of our knowledge, little research has been conducted of the impact of ex vivo ischemia time and delayed processing of biospecimens on hypoxic, stress, apoptotic and autophagic pathways. Therefore, the current study systematically assessed the impact of ex vivo ischemia time and delayed processing time on fresh tissue specimens in terms of the RNA quality and relative mRNA expression of genes involved in hypoxia, stress, apoptosis and autophagy to provide a theoretical basis for the standard processing and assessment of tissue biospecimens. 


\section{Materials and methods}

Procurement of tissues. A total of 18 carcinoma tissue specimens were collected from patients who underwent surgery at Peking Union Medical College Hospital, Beijing, China from April 2017 to June 2017. The clinical characteristics of 18 patients are presented in Table I. The median age of the patients at diagnosis was $49.67 \pm 12.76$ years (range, $29-79$ years), of which 16 patients were female $(88.9 \%)$ and 2 patients were male $(11.1 \%)$. The collected tissues included specimens from 10 patients with thyroid cancer $(55.5 \%), 3$ with ovarian cancer (16.6\%), 2 with breast cancer (11.1\%), 1 with pancreatic cancer $(5.6 \%), 1$ with polymorphous adenocarcinoma $(5.6 \%)$ and 1 with lung cancer (5.6\%). These 18 specimens and 6 types of cancer were included due to their prevalence and commonality in the clinical and tissue biobank. All patients provided signed informed consent for the donation of the specimens. The current study was approved by the Ethics Committee of the Institutional Review Board of Peking Union Medical College Hospital.

Following gross examination, the tissues were resected and washed several times with PBS (pH 7.2) to remove cell debris and remaining blood. Tissues were then dissected into two parts, one part of the specimen $\left(1 \mathrm{~cm}^{3}\right)$ was used for clinical pathology diagnosis, while the other part was divided to 7 smaller specimens (volume, $100 \mathrm{~mm}^{3}$ ). One of the 7 small specimens was immediately snap-frozen in liquid nitrogen, thus the time from tissue resection to storage in liquid nitrogen was $\sim 15 \mathrm{~min}$, which was set as the first point of ex vivo ischemia time. The other 6 specimens were stored at room temperature for $15,45,105,225,465$ and 1,425 min, and then were stored in liquid nitrogen, so the ex vivo ischemia time was $30 \mathrm{~min}, 1,2,4,8$ or $24 \mathrm{~h}$, respectively. Following storage, the specimens were cryopreserved for the subsequent RNA extraction, gene expression analysis and morphological features assessment, which were reviewed by two experienced pathologists to confirm final diagnoses.

RNA extraction and integrity control. Total RNA was extracted from all tissue samples; $30 \mathrm{mg}$ of $30 \mathrm{~mm}^{3}$ tissue specimen was homogenized using TRIzol ${ }^{\circledR}$ reagent (Invitrogen; Thermo Fisher Scientific, Inc.) with a homogenizer (IKA Werke GmbH \& Co. KG) for RNA extraction, according to the manufacturers' protocols. RNA concentration was quantified using NanoDrop ${ }^{\mathrm{TM}}$ One (Thermo Fisher Scientific,Inc.) by measuring the extinction coefficient at $260 \mathrm{~nm}$. Additionally, the ratio of optical density (OD) 260/230 and OD 260/280, which indicates RNA purity, was tested using the NanoDrop One. An Agilent 2100 Bioanalyzer and an Agilent RNA 6000 Nano kit (Agilent Technologies, Inc.) were used to determine RNA quality, according to the manufacturers' protocol. RNA integrity numbers (RINs) were calculated using Agilent Technologies 2100 Bioanalyzer expert software (version B.02.0x; Agilent Technologies, Inc.), and were presented as a value (1-10) to indicate the degree of degradation.

Reverse transcription. Total RNA $(1 \mu \mathrm{g})$ was diluted to a final volume of $25 \mu \mathrm{l}$. A reverse transcription master mix was prepared as follows to reverse transcribe RNA into cDNA: $5 \mu \mathrm{l}$ X reaction buffer, $1 \mu \mathrm{l}$ random primers (cat. no. $\mathrm{C} 1181$;
Table I. Clinical characteristics of the patients $(n=18)$.

Clinical characteristic

Number of patients, $\mathrm{n}(\%)$

$\begin{array}{lr}\text { Sex } & \\ \text { Male } & 2(11.1) \\ \text { Female } & 16(88.9) \\ \text { Age, years } & \\ \leq 50 & 8(44.4) \\ >50 & 10(55.6) \\ \text { Type of carcinoma } & \\ \text { Thyroid } & 10(55.5) \\ \text { Breast } & 3(16.6) \\ \text { Ovary } & 2(11.1) \\ \text { Pancreas } & 1(5.6) \\ \text { Polymorphous adenocarcinoma } & 1(5.6) \\ \text { Lung } & 1(5.6)\end{array}$

Promega Corporation), $1.25 \mu 1$ dNTPs (cat. no. U1330; Promega Corporation), $1 \mu \mathrm{l}$ M-MLV reverse transcriptase (cat. no. M1701; Promega Corporation), $0.5 \mu 1$ RNase inhibitors (Takara Bio, Inc.) and $6.25 \mu \mathrm{l}$ nuclease-free water (cat. no. AM9937; Invitrogen; Thermo Fisher Scientific, Inc.). Following reverse transcription, all samples were diluted to a final volume of $100 \mu \mathrm{l}$.

Reverse transcription-quantitative PCR (RT-qPCR). All PCR procedures were set up using a QIAgility robotic system (Qiagen, Inc.). Mixes were prepared with $5 \mu \mathrm{l}$ Fast SYBR1 Green Master mix (Applied Biosystems; Thermo Fisher Scientific, Inc.; cat. no. 4385612) and $2 \mu \mathrm{l}$ primer mix (1.67 $\mu \mathrm{M}$; Table II). Then, $2 \mu \mathrm{l}$ cDNA (10 ng/ $\mu \mathrm{l})$ were added for a final volume of $10 \mu \mathrm{l} /$ well. Gene expression quantification was performed via RT-qPCR using an Applied Biosystems ${ }^{\circledR}$ 7500 Real-Time PCR system (Thermo Fisher Scientific, Inc.). The following thermocycling conditions were used: $95^{\circ} \mathrm{C}$ for $20 \mathrm{sec}$; followed by 40 cycles of $95^{\circ} \mathrm{C}$ for $3 \mathrm{sec}$ and $60^{\circ} \mathrm{C}$ for $30 \mathrm{sec}$. The expression of the housekeeping gene GAPDH was used for normalization and mRNA levels were quantified using the $2^{-\Delta \Delta \mathrm{Cq}}$ method $(13,14)$. The primers used in the analysis of gene expression were associated with hypoxia, stress, apoptosis and autophagy: Caspase 8 (CASP8), Fas cell surface death receptor (FAS), hypoxia-inducible factor $1 \alpha$ (HIF1 $\alpha)$, unc-51 like autophagy activating kinase 1 (ULK1), mTOR, NF- $\kappa \mathrm{B}$, phosphatidylinositol 4,5-bisphosphate 3-kinase catalytic subunit $\beta$ isoform (PI3KCB), AKT serine/threonine kinase 1 (AKT1), protein kinase AMP-activated catalytic subunit $\alpha 1$ (AMPK $\alpha 1)$ and (Table II).

Histological assessment. The other part of all the fresh tissues specimen were used for the pathological clinical diagnosis. In addition, after the RNA isolation, the frozen thyroid tissues in liquid nitrogen with different ex vivo ischemia times were fixed in $10 \%$ neutral buffered formalin at room temperature for $24 \mathrm{~h}$. Specimens were then embedded in paraffin. Sections (thickness, $5 \mu \mathrm{m}$ ) were microtomed and placed on slides. Slides were baked for $1 \mathrm{~h}$ at $60^{\circ} \mathrm{C}$ in an oven and stained with 
Table II. Primer sequences used for reverse transcription-quantitative PCR.

\begin{tabular}{|c|c|c|}
\hline Gene & Primer sequences $\left(5^{\prime} \rightarrow 3^{\prime}\right)$ & Fragment size, bp \\
\hline \multirow[t]{2}{*}{ CASP8 } & F: GCCCCCATCTATGAGCTGAC & 100 \\
\hline & R: TATCCCCCTGACAAGCCTGA & \\
\hline \multirow[t]{2}{*}{ FAS } & F: GTGGACCCGCTCAGTACG & 121 \\
\hline & R: GGACGATAATCTAGCAACAGACG & \\
\hline \multirow[t]{2}{*}{$\mathrm{HIF} 1 \alpha$} & F: TTGGCAACCTTGGATTGGATG & 190 \\
\hline & R: AAATCTCCGTCCCTCAACCTC & \\
\hline \multirow[t]{2}{*}{ ULK1 } & F: GTCACACGCCACATAACAG & 90 \\
\hline & R: TCTTCTAAGTCCAAGCACAGT & \\
\hline \multirow[t]{2}{*}{ mTOR } & F: GCTTAGAGGACAGCGGGGAA & 120 \\
\hline & R: AAGCATCTTGCCCTGAGGTT & \\
\hline \multirow[t]{2}{*}{$\mathrm{NF}-\kappa \mathrm{B}$} & F: CCACAAGACAGAAGCTGAAG & 149 \\
\hline & R: AGATACTATCTGTAAGTGAACC & \\
\hline \multirow[t]{2}{*}{ PI3KCB } & F: TGGAACTTGGCACTGGAACT & 114 \\
\hline & R: GCTGGGAAACAAGGGGAGAA & \\
\hline \multirow[t]{2}{*}{ AKT1 } & F: CTGGTCCTGTCTTCCTCATGTT & 190 \\
\hline & R: AGGCAGCCCCTTTGACTTCT & \\
\hline \multirow[t]{2}{*}{ AMPK $\alpha 1$} & F: TGAAAGAAAAGTGTGTGCTGT & 64 \\
\hline & R: TGGGTGAGAAGATGAGGGAAAGA & \\
\hline \multirow[t]{2}{*}{ GAPDH } & F: GAAGGTGAAGGTCGGAGTC & 226 \\
\hline & R: GAAGATGGTGATGGGATTTC & \\
\hline
\end{tabular}

bp, base pair; CASP8, caspase 8; FAS, Fas cell surface death receptor; HIF1 $\alpha$, hypoxia-inducible factor 1 $\alpha$; ULK1, unc-51 like autophagy activating kinase 1; PI3KCB, phosphatidylinositol 4,5-bisphosphate 3-kinase catalytic subunit $\beta$ isoform; AKT1, threonine kinase 1; STAT3, signal transduced and activator of transcription.

hematoxylin and eosin, both at room temperature for $1 \mathrm{~h}$ with an autostainer XL (ST5010; Leica Microsystems GmbH). Histological evaluations were completed by two experienced pathologists on a light microscope (magnification, x100 or x200; Axio Scope.A1; Zeiss GmbH).

Statistical analysis. Statistical analysis was performed using SPSS (version 19.0; IBM Corp.) and Prism software (version 5; GraphPad Software, Inc.). One-way ANOVA followed by Tukey's post hoc test was used to analyse differences between multiple groups. Pearson's correlation coefficient was used for correlation analysis. $\mathrm{P}<0.05$ was considered to indicate a statistically significant difference.

\section{Results}

Effect of ex-vivo ischemia time on RNA integrity. To evaluate the influence of tissue ex vivo ischemia time points on RNA integrity under controlled conditions, 18 fresh carcinoma tissues from different organs were collected, separated and stored at room temperature for various ex-vivo ischemia times prior to being snap-frozen in liquid nitrogen. The RNA quality was assessed according to integrity and purity. The RNA integrity data of tissues ex vivo ischemia at $15 \mathrm{~min}, 2$, 8 and $24 \mathrm{~h}$ are presented in Fig. 1A. The distinct ribosomal peaks of $18 \mathrm{~S}$ and $28 \mathrm{~S}$ indicated good RNA integrity at $15 \mathrm{~min}$ and $2 \mathrm{~h}$, but not at 8 and $24 \mathrm{~h}$. The RINs of each group were $8.12 \pm 0.576,7.78 \pm 0.546,7.88 \pm 0.621,7.67 \pm 0.523,7.31 \pm 0.589$,
$7.15 \pm 0.844$ and $6.63 \pm 0.688$ for ex vivo ischemia time points 15, $30 \mathrm{~min}, 1,2,4,8$ and $24 \mathrm{~h}$, respectively (Fig. 1B). SPSS analysis demonstrated that the RINs at 4,8 and $24 \mathrm{~h}$ were significantly decreased compared with $15 \mathrm{~min}(\mathrm{P}<0.001)$. Furthermore, compared with $30 \mathrm{~min}$, RINs at $8 \mathrm{~h}(\mathrm{P}<0.01)$ and $24 \mathrm{~h}(\mathrm{P}<0.001)$ were significantly decreased. Similarly, compared with $1 \mathrm{~h}$, the RINs at $4 \mathrm{~h}(\mathrm{P}<0.05), 8 \mathrm{~h}(\mathrm{P}<0.001)$ and $24 \mathrm{~h}(\mathrm{P}<0.001)$ were decreased, and the RINs at $8 \mathrm{~h}(\mathrm{P}<0.05)$ and $24 \mathrm{~h}(\mathrm{P}<0.001)$ were significantly declined compared with $2 \mathrm{~h}$. In addition, the RINs at $8 \mathrm{~h}$ were decreased compared with $4 \mathrm{~h}(\mathrm{P}<0.01)$, and similarly, the RINs at $24 \mathrm{~h}$ were significantly decreased compared with $8 \mathrm{~h}(\mathrm{P}<0.05)$. The results indicated that RNA remained intact following $2 \mathrm{~h}$ of ex vivo ischemia at room temperature and integrity began to gradually decline after $4 \mathrm{~h}$.

The means of RNA OD260/280 and OD260/230 ratios of 7 time points were $2.05 \pm 0.1$ and $1.78 \pm 0.43$, respectively $(n=126)$. The OD260/280 ratios of each group were $2.028 \pm 0.099,2.101 \pm 0.144,2.043 \pm 0.091,2.051 \pm 0.085$, $2.031 \pm 0.045,2.011 \pm 0.076$ and $2.085 \pm 0.128$ for ex vivo ischemia time points $15,30 \mathrm{~min}, 1,2,4,8$ and $24 \mathrm{~h}$, respectively (Fig. 2). The OD260/230 ratios were $1.713 \pm 0.398,1.960 \pm 0.330$, $1.916 \pm 0.367,1.675 \pm 0.561,1.839 \pm 0.391,1.550 \pm 0.500$ and $1.799 \pm 0.481$ for ex vivo ischemia time points $15,30 \mathrm{~min}, 1$, 2, 4, 8 and $24 \mathrm{~h}$, respectively. The ratios of OD260/280 and OD260/230 of all groups indicated that the degradation of RNA integrity does not affect RNA purity reflected by absorbance under ultraviolet light. 

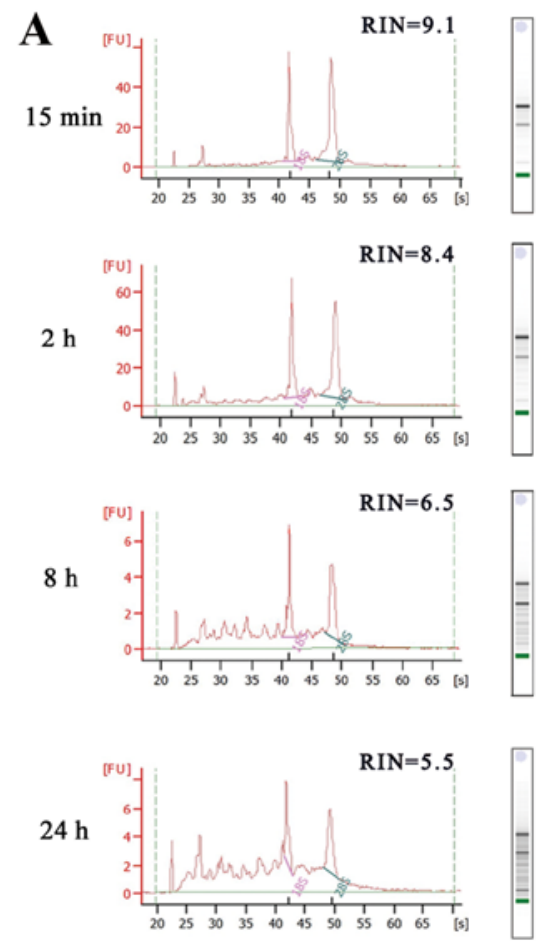

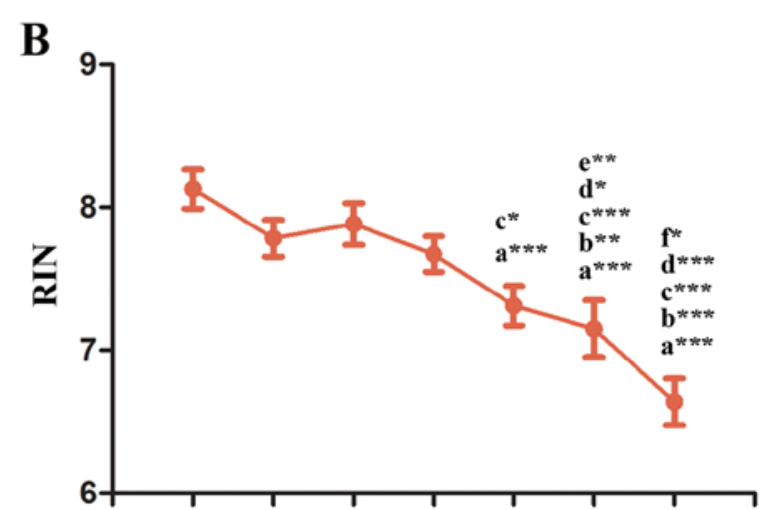

$15 \min 30 \min 1 \mathrm{~h} \quad 2 \mathrm{~h} \quad 4 \mathrm{~h} \quad 8 \mathrm{~h} \quad 24 \mathrm{~h}$

Figure 1. RNA integrity of tissues for various ex vivo ischemia time points. (A) mRNA RINs at 15 min, 2,8 and $24 \mathrm{~h}$ of $e x$ vivo ischemia. (B) Changes in RNA integrity at increasing ex vivo ischemia time points at room temperature. a, vs. $15 \mathrm{~min} ; \mathrm{b}, \mathrm{vs} .30 \mathrm{~min} ; \mathrm{c}, \mathrm{vs} .1 \mathrm{~h} ; \mathrm{d}$, vs. $2 \mathrm{~h} ; \mathrm{e}, \mathrm{vs} .4 \mathrm{~h} ; \mathrm{f}, \mathrm{vs} .8 \mathrm{~h} .{ }^{*} \mathrm{P}<0.05,{ }^{* *} \mathrm{P}<0.01$, ${ }^{* * *} \mathrm{P}<0.001$. RINs, RNA integrity numbers.

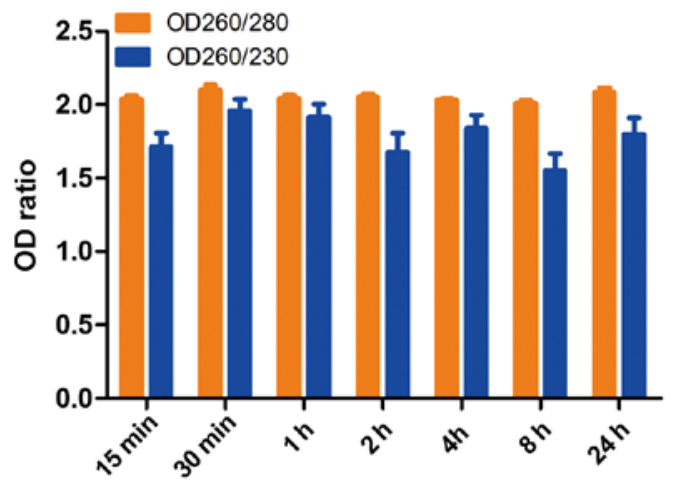

Figure 2. OD260/280 and OD260/230 of isolated RNA for various ex vivo ischemia time points. OD, optical density.

Effect of ex vivo ischemia time on gene expression. To explore the influence of ex vivo ischemia time points on cell functions involving hypoxia, stress, apoptosis and autophagy, the gene expression of mTOR, HIF1 $\alpha$, PI3KCB, AKT1, NF- $\kappa \mathrm{B}$, AMPK $\alpha 1$, CASP8, ULK1 and FAS were evaluated using RT-qPCR. The RINs of the 7 different ex vivo ischemia times indicated that RNA remained intact following $2 \mathrm{~h}$ of ex vivo ischemia at room temperature and integrity began to gradually decline after $4 \mathrm{~h}$. Thus, the present study mainly focused on ex vivo ischemia times of $15 \mathrm{~min}, 2,8$ and $24 \mathrm{~h}$, and more times will be explored in further study. The results demonstrated that AKT1 was significantly decreased at $8 \mathrm{~h}$ compared with $15 \mathrm{~min}$ $(\mathrm{P}<0.01)$ and that PI3KCB, AMPK $\alpha 1$ and CASP8 were significantly decreased at $24 \mathrm{~h}$ compared with $15 \mathrm{~min}(\mathrm{P}<0.05$; Fig. 3$)$. However, the expression of mTOR, HIF $1 \alpha, \mathrm{NF}-\kappa \mathrm{B}, \mathrm{ULK} 1$ and FAS were not significantly different between time points.
Further analysis indicated that there was no significant correlation between RIN and gene expression (Table III). In addition, the interclass Pearson correlation coefficients among the gene expression levels were strong, such as $\mathrm{r}_{\mathrm{mTOR} / \mathrm{PI} 3 \mathrm{KCB}}=0.721, \mathrm{r}_{\mathrm{mTOR} / \mathrm{AKTl}}=0.792, \mathrm{r}_{\mathrm{mTOR} / \mathrm{NF}-\mathrm{\kappa B}}=0.640$, $\mathrm{r}_{\mathrm{mTOR} / \mathrm{AMPK} \alpha 1}=0.630, \mathrm{r}_{\mathrm{PI} 3 \mathrm{KCB} / \mathrm{AKT} 1}=0.741, \mathrm{r}_{\mathrm{PI} 3 \mathrm{KCB} / \mathrm{NF}-\mathrm{\kappa B}}=0.572$, $\mathrm{r}_{\mathrm{PI} 3 K \mathrm{~KB} / \mathrm{AMPK} \alpha 1}=0.835, \mathrm{r}_{\mathrm{AKT} 1 / \mathrm{NF}-\mathrm{kB}}=0.646$ and $\mathrm{r}_{\mathrm{AKT} 1 / \mathrm{AMPK} \alpha 1}=0.666$, $\mathrm{r}_{\mathrm{AKT} 1 / \mathrm{CASP} 8}=0.508, \mathrm{r}_{\mathrm{CASP} 8 / \mathrm{FAS}}=0.762, \mathrm{r}_{\mathrm{CASP} 8 / \mathrm{mTOR}}=0.607$, $\mathrm{r}_{\mathrm{HIF} 1 \alpha / \mathrm{ULK} 1}=0.728(\mathrm{P}<0.001)$ (Table IV). In addition, HIF1 $\alpha$ had slight positive correlation with mTOR, PI3KCB and AKT1 ( $r=0.281, r=0.293$ and $r=0.298$, respectively; $\mathrm{P}<0.05)$, and FAS has correlation with $\mathrm{NF}-\kappa \mathrm{B}(\mathrm{r}=0.281 ; \mathrm{P}<0.05)$. In addition, there were no correlations observed between some gene expression $(\mathrm{P}>0.05)$, such as AKT1 vs. FAS, ULK1 vs. AKT1, AMPK $\alpha 1$ vs. FAS, ULK1 vs. mTOR, ULK1 vs. PI3KCB, ULK1 vs. NF- $\kappa$ B and FAS vs. PI3KCB. A scatter plot of gene expression, including the correlation between the expression of these genes is presented in Fig. 4; the scatterplot trend was consistent with the correlation coefficients of the gene expression presented in Table IV.

Histological morphology. To evaluate histomorphology at various ex vivo ischemia time points, frozen tissue specimens were fixed, sectioned and stained with H\&E. The histological morphology demonstrated that follicular epithelial cells were arranged closely and maintained integrity at $15 \mathrm{~min}$ and $2 \mathrm{~h}$ in thyroid tissues (Fig. 5). However, the microstructure of the thyroid follicles was destroyed at $8 \mathrm{~h}$ and cells displayed looseness and follicle disintegration at $24 \mathrm{~h}$. These results demonstrated that ex vivo ischemia and delayed processing induced morphological changes in thyroid carcinoma, which was accompanied by RNA degradation. 
Table III. Correlation coefficients between RIN and gene expression.

RIN

Gene

Pearson correlation coefficient

Significance (bilateral)

mTOR

$-0.065$

0.590

PI3KCB

$-0.051$

0.668

AKT1

0.172

0.150

$\mathrm{NF}-\kappa \mathrm{B}$

0.102

0.394

HIF1 $\alpha$

0.018

0.882

AMPK $\alpha 1$

$-0.040$

0.741

CASP8

0.133

0.267

FAS

0.066

0.582

ULK1

0.024

0.840

RIN, RNA integrity number; PI3KCB, phosphatidylinositol 4,5-bisphosphate 3-kinase catalytic subunit $\beta$ isoform; AKT1, threonine kinase 1; HIF $1 \alpha$, hypoxia-inducible factor $1 \alpha$; AMPK $\alpha 1$, protein kinase AMP-activated catalytic subunit $\alpha 1$; CASP8, caspase 8 ; FAS, Fas cell surface death receptor; ULK1, unc-51 like autophagy activating kinase 1.
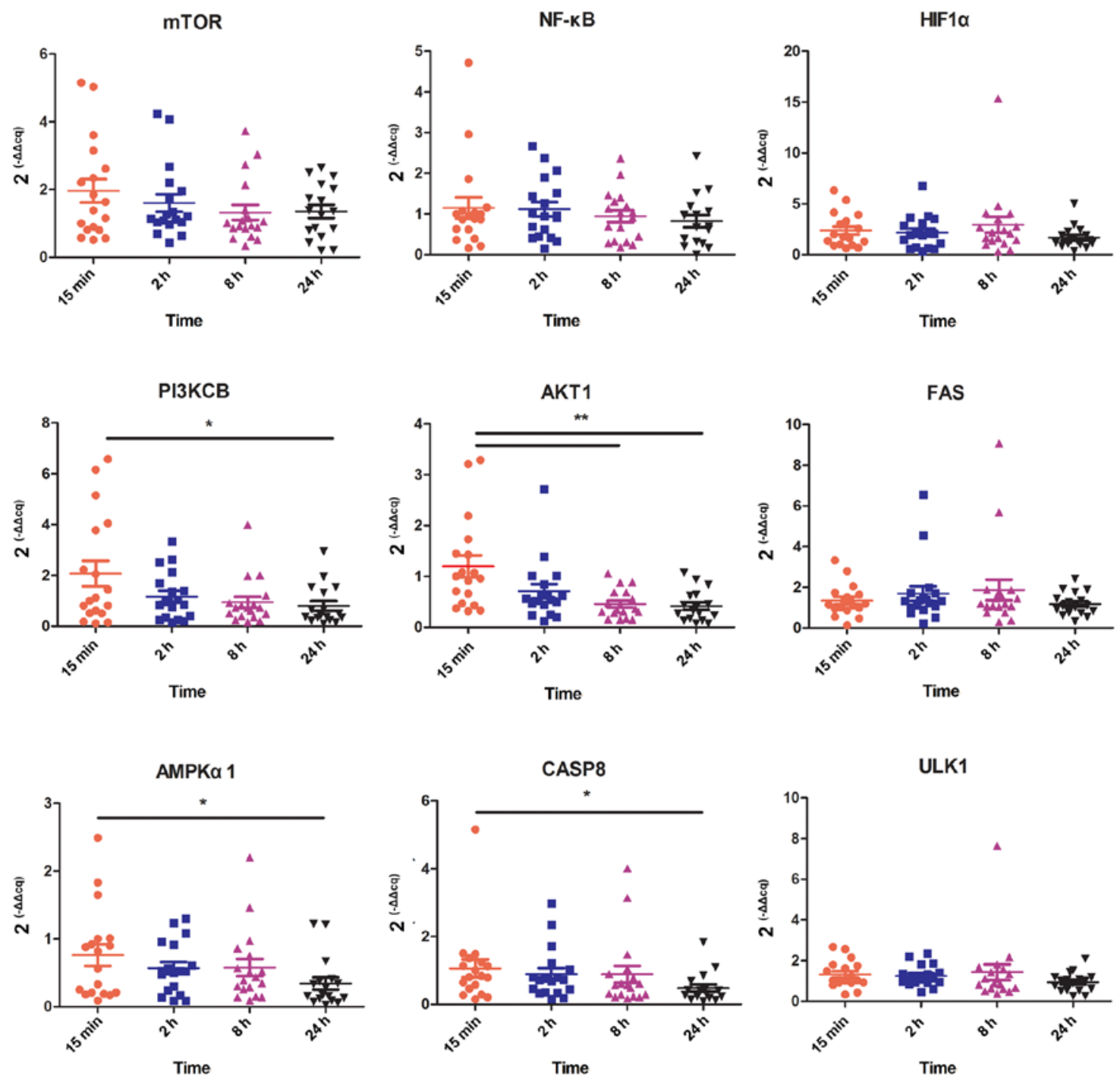

Figure 3. Gene expression of genes associated with hypoxic, stress, apoptotic and autophagic pathways for various ex vivo ischemia time points. HIF1a, hypoxia-inducible factor $1 \alpha$; PI3KCB, phosphatidylinositol 4,5-bisphosphate 3-kinase catalytic subunit $\beta$ isoform; AKT1, threonine kinase 1; FAS, Fas cell surface death receptor; AMPK $\alpha 1$, protein kinase AMP-activated catalytic subunit $\alpha 1$; CASP8, caspase 8; ULK1, unc-51 like autophagy activating kinase 1. ${ }^{*} \mathrm{P}<0.05,{ }^{* *} \mathrm{P}<0.01$. 
Table IV. Pearson's correlation coefficients of gene expression.

\begin{tabular}{|c|c|c|c|c|c|c|c|c|c|}
\hline \multirow[b]{2}{*}{ Variable } & \multicolumn{9}{|c|}{ Gene expression } \\
\hline & mTOR & PI3KCB & AKT1 & $\mathrm{NF}-\kappa \mathrm{B}$ & HIF1 $\alpha$ & AMPK $\alpha 1$ & CASP8 & FAS & ULK1 \\
\hline \multicolumn{10}{|l|}{ mTOR } \\
\hline r-value & 1 & $0.721^{\mathrm{c}}$ & $0.792^{\mathrm{c}}$ & $0.640^{\mathrm{c}}$ & $0.281 \mathrm{a}$ & $0.630^{c}$ & $0.607^{\mathrm{c}}$ & $0.409^{\mathrm{c}}$ & 0.221 \\
\hline Significance (bilateral) & N/A & 0.000 & 0.000 & 0.000 & 0.017 & 0.000 & 0.000 & 0.000 & 0.063 \\
\hline $\mathrm{N}$ & 72 & 72 & 72 & 72 & 72 & 72 & 72 & 72 & 72 \\
\hline \multicolumn{10}{|l|}{ PI3KCB } \\
\hline r-value & $0.721^{\mathrm{c}}$ & 1 & $0.741^{\mathrm{c}}$ & $0.572^{c}$ & $0.293^{\mathrm{a}}$ & $0.835^{\mathrm{c}}$ & $0.372^{\mathrm{b}}$ & 0.019 & 0.150 \\
\hline Significance (bilateral) & 0.000 & $\mathrm{~N} / \mathrm{A}$ & 0.000 & 0.000 & 0.013 & 0.000 & 0.001 & 0.876 & 0.208 \\
\hline $\mathrm{N}$ & 72 & 72 & 72 & 72 & 72 & 72 & 72 & 72 & 72 \\
\hline \multicolumn{10}{|l|}{ AKT1 } \\
\hline r-value & $0.792^{c}$ & $0.741^{\mathrm{c}}$ & 1 & $0.646^{\mathrm{c}}$ & $0.298^{\mathrm{a}}$ & $0.666^{\mathrm{c}}$ & $0.508^{c}$ & 0.181 & 0.189 \\
\hline Significance (bilateral) & 0.000 & 0.000 & $\mathrm{~N} / \mathrm{A}$ & 0.000 & 0.011 & 0.000 & 0.000 & 0.127 & 0.111 \\
\hline $\mathrm{N}$ & 72 & 72 & 72 & 72 & 72 & 72 & 72 & 72 & 72 \\
\hline \multicolumn{10}{|l|}{$\mathrm{NF}-\kappa \mathrm{B}$} \\
\hline r-value & $0.640^{c}$ & $0.572^{c}$ & $0.646^{\mathrm{c}}$ & 1 & 0.226 & $0.674^{\mathrm{c}}$ & $0.658^{c}$ & $0.281^{\mathrm{a}}$ & 0.021 \\
\hline Significance (bilateral) & 0.000 & 0.000 & 0.000 & N/A & 0.056 & 0.000 & 0.000 & 0.017 & 0.861 \\
\hline $\mathrm{N}$ & 72 & 72 & 72 & 72 & 72 & 72 & 72 & 72 & 72 \\
\hline \multicolumn{10}{|l|}{$\mathrm{HIF} 1 \alpha$} \\
\hline r-value & $0.281^{\mathrm{a}}$ & $0.293^{\mathrm{a}}$ & $0.298^{\mathrm{a}}$ & 0.226 & 1 & $0.433^{\mathrm{c}}$ & $0.525^{\mathrm{c}}$ & $0.482^{\mathrm{c}}$ & $0.728^{c}$ \\
\hline Significance (bilateral) & 0.017 & 0.013 & 0.011 & 0.056 & $\mathrm{~N} / \mathrm{A}$ & 0.000 & 0.000 & 0.000 & 0.000 \\
\hline $\mathrm{N}$ & 72 & 72 & 72 & 72 & 72 & 72 & 72 & 72 & 72 \\
\hline \multicolumn{10}{|l|}{$\mathrm{AMPK} \alpha 1$} \\
\hline r-value & $0.630^{\mathrm{c}}$ & $0.835^{\mathrm{c}}$ & $0.666^{\mathrm{c}}$ & $0.674^{\mathrm{c}}$ & $0.433^{\mathrm{c}}$ & 1 & $0.557^{\mathrm{c}}$ & 0.137 & $0.342^{\mathrm{c}}$ \\
\hline Significance (bilateral) & 0.000 & 0.000 & 0.000 & 0.000 & 0.000 & N/A & 0.000 & 0.250 & 0.003 \\
\hline $\mathrm{N}$ & 72 & 72 & 72 & 72 & 72 & 72 & 72 & 72 & 72 \\
\hline \multicolumn{10}{|l|}{ CASP8 } \\
\hline r-value & $0.607^{\mathrm{c}}$ & $0.372^{\mathrm{c}}$ & $0.508^{c}$ & $0.658^{\mathrm{c}}$ & $0.525^{\mathrm{c}}$ & $0.557^{\mathrm{c}}$ & 1 & $0.762^{c}$ & $0.467^{\mathrm{c}}$ \\
\hline Significance (bilateral) & 0.000 & 0.001 & 0.000 & 0.000 & 0.000 & 0.000 & $\mathrm{~N} / \mathrm{A}$ & 0.000 & 0.000 \\
\hline $\mathrm{N}$ & 72 & 72 & 72 & 72 & 72 & 72 & 72 & 72 & 72 \\
\hline \multicolumn{10}{|l|}{ FAS } \\
\hline r-value & $0.409^{c}$ & 0.019 & 0.181 & $0.281^{\mathrm{a}}$ & $0.482^{\mathrm{c}}$ & 0.137 & $0.762^{c}$ & 1 & $0.501^{\mathrm{c}}$ \\
\hline Significance (bilateral) & 0.000 & 0.876 & 0.127 & 0.017 & 0.000 & 0.250 & 0.000 & $\mathrm{~N} / \mathrm{A}$ & 0.000 \\
\hline $\mathrm{N}$ & 72 & 72 & 72 & 72 & 72 & 72 & 72 & 72 & 72 \\
\hline \multicolumn{10}{|l|}{ ULK1 } \\
\hline r-value & 0.221 & 0.150 & 0.189 & 0.021 & $0.728^{c}$ & $0.342^{\mathrm{b}}$ & $0.467^{\mathrm{c}}$ & $0.501^{\mathrm{c}}$ & 1 \\
\hline Significance (bilateral) & 0.063 & 0.208 & 0.111 & 0.861 & 0.000 & 0.003 & 0.000 & 0.000 & $\mathrm{~N} / \mathrm{A}$ \\
\hline $\mathrm{N}$ & 72 & 72 & 72 & 72 & 72 & 72 & 72 & 72 & 72 \\
\hline
\end{tabular}

${ }^{\mathrm{a}} \mathrm{P}<0.05,{ }^{\mathrm{b}} \mathrm{P}<0.01,{ }^{\mathrm{c}} \mathrm{P}<0.001$. $\mathrm{PI} 3 \mathrm{KCB}$, phosphatidylinositol 4,5-bisphosphate 3-kinase catalytic subunit $\beta$ isoform; AKT1, threonine kinase 1; HIF1 $\alpha$, hypoxia-inducible factor $1 \alpha$; AMPK $\alpha 1$, protein kinase AMP-activated catalytic subunit $\alpha 1$; CASP8, caspase 8; FAS, Fas cell surface death receptor; ULK1, unc-51 like autophagy activating kinase 1; N/A, not applicable.

\section{Discussion}

RNA degradation is one of the major issues when storing tissues in biobanks, and previous studies have investigated the effect of tissue type, storage buffers and ex vivo ischemia times on RNA quality $(15,16)$. Among these factors, ex vivo ischemia and delayed processing time are crucial pre-analysis challenges for RNA quality $(6,12)$. The results of the current study demonstrated that RNA integrity decreased significantly following ex vivo ischemia for $4 \mathrm{~h}$, indicating that RNA remained intact for $2 \mathrm{~h}$ at room temperature.

Previous research reported that the effects of ex vivo ischemia time on RNA integrity varied in different types of tumors. Bao et al (17) demonstrated that RNA remained stable both at room temperature and on ice for $\leq 4 \mathrm{~h}$ in colon cancer tissues. Additionally, retained ileum mucosa was revealed to exhibit high 


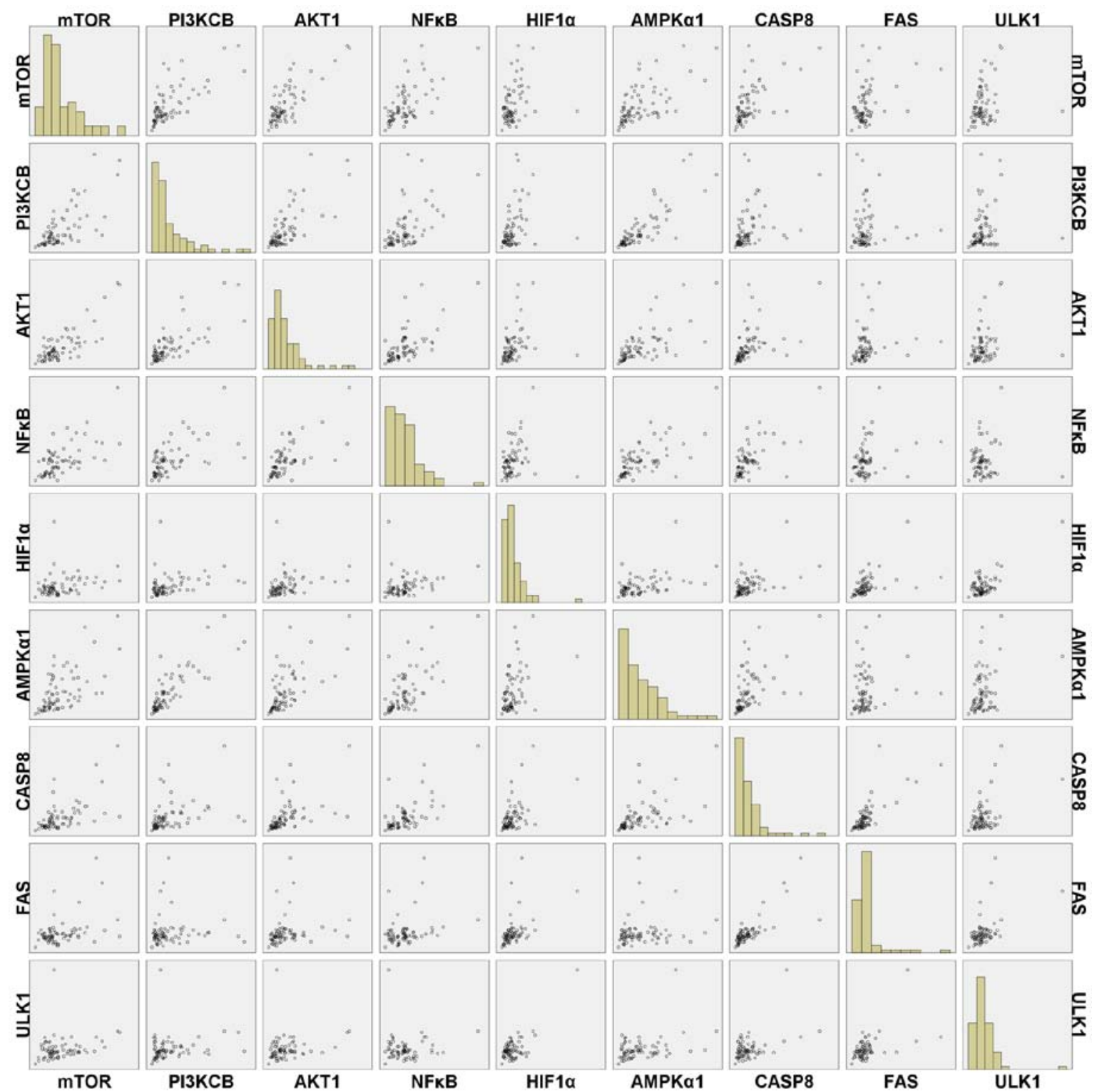

Figure 4. Scatter plots of the expression of genes associated with hypoxic, stress, apoptotic and autophagic pathways for various ex vivo ischemia time points. PI3KCB, phosphatidylinositol 4,5-bisphosphate 3-kinase catalytic subunit $\beta$ isoform; AKT1, threonine kinase 1; HIF1 $\alpha$, hypoxia-inducible factor $1 \alpha$; AMPK $\alpha 1$, protein kinase AMP-activated catalytic subunit $\alpha 1$; CASP8, caspase 8; FAS, Fas cell surface death receptor; ULK1, unc-51 like autophagy activating kinase 1.

RNA integrity for $1.5 \mathrm{~h}$ at room temperature and $6 \mathrm{~h}$ at $4^{\circ} \mathrm{C}(18)$. In kidney renal cell carcinoma tissues, RNA degradation was observed at room temperature for $1 \mathrm{~h}$ and degradation was not detected following storage on ice for 4 h $(19,20)$. Similarly, RIN gradually decreased in tumor and adjacent normal tissues at $24^{\circ} \mathrm{C}$ at ischemia time points $15,30,60$ and $120 \mathrm{~min}$ in hepatocellular carcinoma tissues (21). Even though our study did not verify whether the RNA integrity from different tumor tissues (such as thyroid, ovary, breast, pancreas, jaw and lung) had different sensitivities to ex vivo ischemia time points, it could be verified by further studies with more carcinoma specimens.

In addition, a previous study demonstrated that the RIN of non-small cell lung cancer tissue was significantly lower $(\mathrm{OR}=0.08 ; \mathrm{P}=0.01)$ in samples that were preserved for $>3 \mathrm{~h}$ prior to cryopreservation, and prolonged in vivo $(>2 \mathrm{~h})$ and ex vivo ischemia $(>10 \mathrm{~h})$ times were associated with lower patient-derived xenograft engraftment rates (22). Furthermore, long term ex vivo ischemia of human brain tumor biopsy tissues affected ribosomal RNA integrity and increased RNA degradation (23). When snap freezing and multiple sampling of biopsies were combined, the percentage of specimens with degraded RNA was reduced by two-fold (23). However, another previous study on RNA integrity and gene expression in human myocardial tissue reported that there was no significant correlation between RIN and a post-mortem interval of 5-24 h at $4^{\circ} \mathrm{C}$ (24). Furthermore, RNA integrity was not correlated with $1 \mathrm{~h}$ ex vivo ischemia time points in different types of tumors, including breast, colon, stomach, oesophageal, gall bladder, ovarian, kidney, liver, lung, pancreatic, small intestinal, spleen, common bile duct, retroperitoneum, testis and urinary bladder cancer $(24,25)$.

Additionally, the duration of ex vivo ischemia affects the related gene expression profile (20). The results of the current study demonstrated that the gene expression of PI3KCB, AKT1, 
A

$2 \mathrm{~h}$

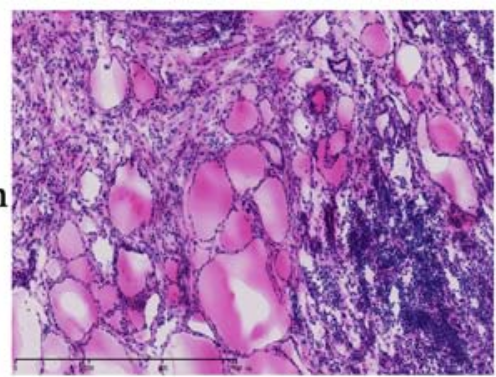

$15 \mathrm{~min}$

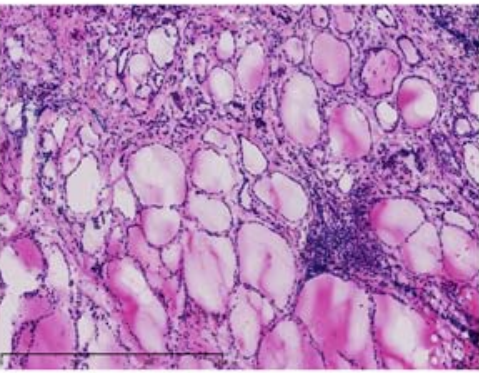

$8 \mathrm{~h}$

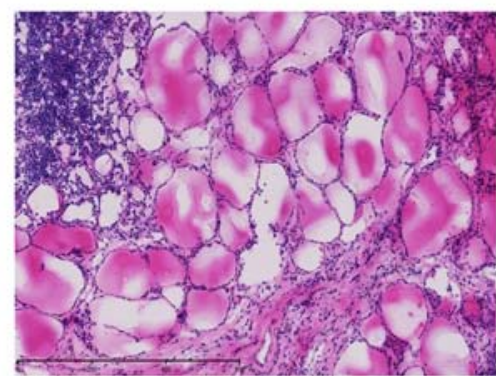

$24 \mathrm{~h}$

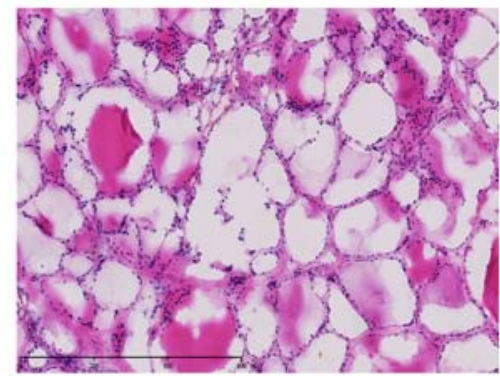

B
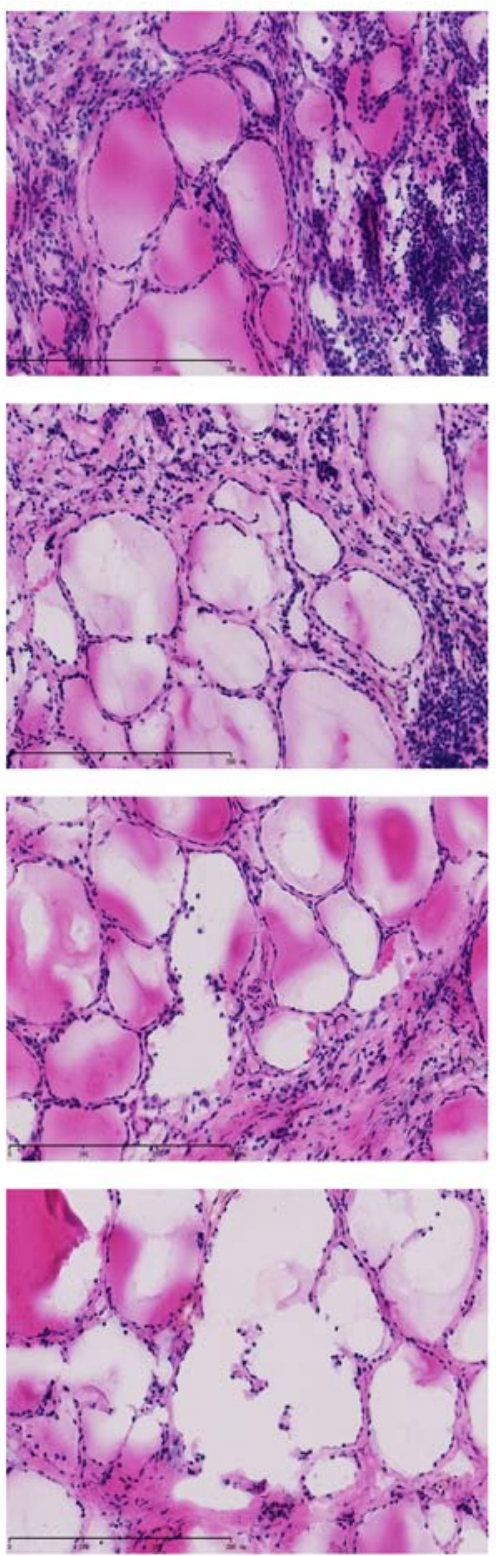

Figure 5. Haematoxylin and eosin-stained thyroid tissues at various ex vivo ischemia time points. Thyroid tissues at ex vivo ischemia time points of 15 min, 2 , 8 and $24 \mathrm{~h}$ at (A) magnification $\times 100$ and (B) magnification $\times 200$.

AMPK $\alpha 1$ and CASP8 were significantly decreased following ex vivo ischemia at time points 8-24 h compared with 15 min. PI3KCB, AKT1, AMPK $\alpha 1$ and CASP8 serve important roles in the hypoxic, stress, apoptotic and autophagic signaling pathways $(26,27)$. AMPK $\alpha 1$ is critical for hypoglycemia, hypoxia, ischemia and heat shock (28), and regulates growth, metabolism reprogramming, glucose and fatty acid metabolism and mitochondrial function (29). Oncogenes AKT1 and PI3KCB are major factors in the regulation of various cellular functions, including metabolism, growth, proliferation, survival, transcription and protein synthesis $(30,31)$. Furthermore, AMPK $\alpha 1$ stimulates autophagy by inhibiting mTOR, whereas PI3KCB, Ras and AKT1 inhibit autophagy by activating mTOR (32). Additionally, CASP8 is induced by endoplasmic reticulum stress and proteotoxic stress (33), which participate in the apoptosis signal pathway (34).

An increased number of studies have demonstrated that when the blood supply is cut off, tissues undergo oxygen deprivation and mammalian cells undergo hypoxemia, autophagy and endoplasmic reticulum stress response (35). Then, hypoxemia, autophagy, apoptosis and endoplasmic reticulum stress occur and coordinate $(36,37)$. Furthermore, a previous study has reported that exposure to ex vivo ischemia significantly altered gene expression of G-protein signaling 1 and eukaryotic translation elongation factor $1 \alpha 1$ in normal and colorectal cancer tissue samples (38).

Dr Carolyn Compton, a former Office of Biorepository and Biospecimen Research executive, proposed that when biological samples are excised, cut off from a blood supply and exposed to abrupt changes in temperature, cellular behavior becomes difficult to predict (4). Gene expression and protein phosphorylation fluctuate extensively and cellular self-destruct pathways may be activated (4). The American Society of Clinical Oncology, College of American Pathologists (2014), Biorepositories and Biospecimen Research Branch, National Cancer Institute (2016), Clinical Laboratory Standards 
Institute (2011), Clinical Laboratory Standards Institute (2005), International Standards Organization/Technical Committee (2016) and European Committee for Standardization/Technical Committee (2015) demonstrated that ex vivo ischemia times in tissues should be as short as possible (optimally $<20 \mathrm{~min}$ and not $>1 \mathrm{~h}$ ) for the analysis of biomarkers, molecular analysis, and RNA, DNA and protein isolation (6).

Although the results of the current study revealed that the expression of PI3KCB, AKT1, AMPK $\alpha 1$ and CASP8 decreased with time, there was no correlation between RIN and gene expression, indicating that the decrease in gene expression was not induced by RNA degradation. Instead, the decrease in gene expression was associated with hypoxia, stress, apoptosis and autophagy induced by ex vivo ischemia and delayed processing.

Furthermore, the results demonstrated positive correlations between the expression of mTOR, PI3KCB, AKT1, NF- $\mathrm{KB}$ and AMPK $\alpha 1$, indicating that their expression levels may be coordinated during ex vivo ischemia and delayed processing. Certain stress responsive transcription factors, including $\mathrm{NF}-\kappa \mathrm{B}$, serve a major role in autophagic response (39) and orchestrate numerous transcriptional responses, including autophagy and execution of cell death (40). Wang et al (26) reported that endoplasmic reticulum stress and mitochondrial injury on myocardial ischemia and reperfusion upregulated phosphorylated PI3KCB and AKT1. Hypoxia and reperfusion can evoke autophagy and apoptosis via the AKT1 and mTOR signaling pathways in microglia cells and the expression of mTOR and AKT1 was not altered under hypoxic conditions for $6 \mathrm{~h}$ and reperfusion injury at 24; however, the levels of p-AKT1 and mTOR were altered (27). Thus, the results of the current study indicated that while mRNA expression was altered due to ex vivo ischemia and delayed processing, whether the expression of phosphorylated proteins, which is important in cell signal transduction, may be altered requires further study.

Furthermore, the results demonstrated that there were fewer positive correlations between HIF $1 \alpha$ and mTOR, PI3KCB and AKT1. A prior study revealed that HIF1 $\alpha$ promotes the expression of hundreds of genes involved in autonomous and non-autonomous cellular adaptations to hypoxia, which are upregulated at the protein level via mTOR or at the mRNA level via STAT3 and NF- $\mathrm{KB}$ signaling (41). Although the current study did not report ULK and/or FAS downregulation at the mRNA level or an association with the other factors, the activity of ULK is required for autophagy (42). ULK-mediated Beclin-1 phosphorylation in vivo is crucial for the function of Beclin-1 in autophagy (42).

Moreover, in addition to RNA degradation, the results of the present study showed that ex vivo ischemia and delayed processing induced morphological changes in thyroid carcinoma tissues, which is another factor to be evaluated following delayed processing.

In addition to the processing variables, biological and environmental factors, including donor sex, age (43), drug use (44) and diet, exercise and lifestyle habits, such as smoking, could affect the quality of biospecimens (45). Furthermore, various acquisition methods, such as collecting during the surgical operation (in situ) or after resection (ex vivo) (9), and surgical approaches, such as laparoscopic colectomy or open colectomy (8) could influence gene expression analysis.
There were certain limitations of the present study. Firstly, the current study was a preliminary study that could not verify whether RNA integrity from various tumor tissues had different sensitivities to ex vivo ischemia time due to the small sample size. Future studies should include larger sample sizes and more tumor specimens to comprehensively examine the effects of various ex vivo ischemia time points and delayed processing on RNA integrity and tissue quality in different carcinoma tissues. Secondly, tissue biobanks are the basic infrastructure that provide biospecimens to various institutions for basic, translational and clinical research, and their procedures for the collection, analysis, storage and distribution of biospecimens may affect the results of downstream studies. Furthermore, tissue banks should set up individual procedures according to the requirements by researchers to accommodate research institutions that require tissues for specific purposes. Therefore, a future study should investigate the commonality of more tissues in biobanks, such as breast, colon, stomach, oesophagus, gall bladder, ovary, kidney, liver, lung and pancreas, which could be used to provide research institutions with standardized processing procedures for specimens.

In conclusion, ex vivo ischemia time and delayed processing induced RNA degradation and altered gene expression in various carcinoma tissues. Fresh tissues should be processed within $2 \mathrm{~h}$ to avoid RNA degradation to acquire high quality biospecimens. Furthermore, the gene expression of PI3KCB, AKT1, AMPK $\alpha 1$ and CASP8 may be considered as markers to evaluate tissue quality at the gene expression level, providing a method for the standard processing and assessment of tissue specimens.

\section{Acknowledgements}

Not applicable.

\section{Funding}

The current study was supported by the Chinese Academy of Medical Sciences Initiative for Innovative Medicine (grant nos. 2017-I2M-1-001 and 2017-I2M-2-001) and The National Key Research and Development Program of China: The Cluster Construction of Human Genetic Resource Biobank in North China (grant no. 2016YFC1201703).

\section{Availability of data and materials}

All data generated or analyzed during the current study are included in this published article.

\section{Authors' contributions}

$\mathrm{AW}, \mathrm{SZ}$ and DC processed the tissue specimens, performed the RNA extraction and qPCR. DG and TX designed the study, contributed to the analysis of the data and wrote the manuscript. JS performed the histological analysis and interpreted the patient data. All authors read and approved the final manuscript.

\section{Ethics approval and consent to participate}

All patients provided signed informed consent for the donation of the specimens. The current study was approved by the 
Ethics Committee of the Institutional Review Board of Peking Union Medical College Hospital.

\section{Patient consent for publication}

Not applicable.

\section{Competing interests}

The authors declare that they have no competing interests.

\section{References}

1. Watson PH, Wilson-McManus JE, Barnes RO, Barnes, Giesz SC, Png A, Hegele RG, Brinkman JN, Mackenzie IR, Huntsman DG, Junker A, et al: Evolutionary concepts in biobanking-the BC BioLibrary. J Transl Med 7: 95, 2009.

2. Nishihara H: Clinical biobank: A novel system to support cancer clinical sequencing in Japan. Rinsho Byori 65: 167-172, 2017 (In Japanese).

3. Ginsburg GS, Burke TW and Febbo P: Centralized biorepositories for genetic and genomic research. JAMA 299: 1359-1361, 2008.

4. Baker M: Biorepositories: Building better biobanks. Nature 486: 141-146, 2012.

5. Carithers LJ, Agarwal R, Guan P, Odeh H, Sachs MC, Engel KB, Greytak SR, Barcus M, Soria C, Jason Lih CJ, et al: The biospecimen preanalytical variables program: A multiassay comparison of effects of delay to fixation and fixation duration on nucleic acid quality. Arch Pathol Lab Med 143: 1106-1118, 2019.

6. Compton CC, Robb JA, Anderson MW, Berry AB, Birdsong GG, Bloom KJ, Branton PA, Crothers JW, Cushman-Vokoun AM, Hicks DG, et al: Preanalytics and precision pathology: Pathology practices to ensure molecular integrity of cancer patient biospecimens for precision medicine. Arch Pathol Lab Med 143: 1346-1363, 2019.

7. Kahn N, Riedlinger J, Roessler M, Rabe C, Lindner M, Koch I, Schott-Hildebrand S, Herth FJ, Schneider MA, Meister M and Muley TR: Blood-sampling collection prior to surgery may have a significant influence upon biomarker concentrations measured. Clin Proteomics 12: 19, 2015.

8. Galissier T, Schneider C, Nasri S, Kanagaratnam L, Fichel C, Coquelet C, Diebold MD, Kianmanesh R, Bellon G, Dedieu $\mathrm{S}$, et al: Biobanking of fresh-frozen human adenocarcinomatous and normal colon tissues: Which parameters influence RNA quality? PLoS One 11: e0154326, 2016.

9. Zhou JH, Sahin AA and Myers JN: Biobanking in genomic medicine. Arch Pathol Lab Med 139: 812-818, 2015.

10. Olsen J, Kirkeby LT, Eiholm S, Jess P, Troelsen JT, Gögenür I and Olsen J: Impact of in vivo ischemic time on RNA quality-experiences from a colon cancer biobank. Biopreserv Biobank 13: 255-262, 2015

11. Zheng XH, Zhang SD, Zhang PF, Li XZ, Hu YZ, Tian T, Zhu L, Wang RZ and Jia WH: Tumor cell content and RNA integrity of surgical tissues from different types of tumors and its correlation with ex vivo and in vivo ischemia. Ann Surg Oncol 25 3764-3770, 2018.

12. Betsou F, Lehmann S, Ashton G, Barnes M, Benson EE, Coppola D, DeSouza Y, Eliason J, Glazer B, Guadagni F, et al: Standard preanalytical coding for biospecimens: Defining the sample PREanalytical code. Cancer Epidemiol Biomarkers Prev 19: 1004-1011, 2010.

13. Mazzei M, Vascellari M, Zanardello C, Melchiotti E, Vannini S Forzan M, Marchetti V, Albanese F and Abramo F: Quantitative real time polymerase chain reaction (qRT-PCR) and RNAscope in situ hybridization (RNA-ISH) as effective tools to diagnose feline herpesvirus-1-associated dermatitis. Vet Dermatol 30: 491-e147, 2019

14. Livak KJ and Schmittgen TD: Analysis of relative gene expression data using real-time quantitative PCR and the 2(-Delta Delta C(T)) method. Methods 25: 402-408, 2001.

15. Micke P, Ohshima M, Tahmasebpoor S, Ren ZP, Ostman A, Pontén F and Botling J: Biobanking of fresh frozen tissue: RNA is stable in nonfixed surgical specimens. Lab Invest 86: 202-211, 2006.
16. Rudloff U, Bhanot U, Gerald W, Klimstra DS, Jarnagin WR, Brennan MF and Allen PJ: Biobanking of human pancreas cancer tissue: Impact of ex-vivo procurement times on RNA quality. Ann Surg Oncol 17: 2229-2236, 2010.

17. Bao WG, Zhang X, Zhang JG, Zhou WJ, Bi TN, Wang JC, Yan WH and Lin A: Biobanking of fresh-frozen human colon tissues: Impact of tissue ex-vivo ischemia times and storage periods on RNA quality. Ann Surg Oncol 20: 1737-1744, 2013.

18. Lee SM, Schelcher C, Thasler R, Schiergens TS and Thasler WE: Pre-analytical determination of the effect of extended warm or cold ischaemia on RNA stability in the human ileum mucosa. PLoS One 10: $\mathrm{e} 0138214,2015$.

19. Jeck WR, Sorrentino JA, Wang K, Slevin MK, Burd CE, Liu J, Marzluff WF and Sharpless NE: Circular RNAs are abundant, conserved, and associated with ALU repeats. RNA 19: 141-157, 2013.

20. Sun H, Sun R, Hao M, Wang Y, Zhang X, Liu Y and Cong X: Effect of duration of ex vivo ischemia time and storage period on RNA quality in biobanked human renal cell carcinoma tissue. Ann Surg Oncol 23: 297-304, 2016.

21. Zheng H, Tao YP, Chen FQ, Li HF, Zhang ZD, Zhou XX, Yang Y and Zhou WP: Temporary ischemia time before snap freezing is important for maintaining high-integrity RNA in hepatocellular carcinoma tissues. Biopreserv Biobank 17: 425-432, 2019.

22. Guerrera F, Tabbo F, Bessone L, Maletta F, Gaudiano M, Ercole E, Annaratone L, Todaro M, Boita M, Filosso PL, et al: The influence of tissue ischemia time on RNA integrity and patient-derived xenografts (PDX) engraftment rate in a non-small cell lung cancer (NSCLC) biobank. PLoS One 11: e0145100, 2016.

23. Castells Domingo X, Ferrer-Font L, Davila M, Candiota AP, Simões RV, Fernández-Coello A, Gabarrós A, Boluda S, Barceló A, Ariño J and Arús C: Improving ribosomal RNA integrity in surgically resected human brain tumor biopsies. Biopreserv Biobank 14: 156-164, 2016.

24. Gonzalez-Herrera L, Valenzuela A, Marchal JA, Lorente JA and Villanueva E: Studies on RNA integrity and gene expression in human myocardial tissue, pericardial fluid and blood, and its postmortem stability. Forensic Sci Int 232: 218-228, 2013.

25. Song SY, Jun J, Park M, Park SK, Choi W, Park K, Jang KT and Lee M: Biobanking of fresh-frozen cancer tissue: RNA is stable independent of tissue type with less than 1 hour of cold ischemia. Biopreserv Biobank 16: 28-35, 2018.

26. Wang Z, Wang Y, Ye J, Lu X, Cheng Y, Xiang L, Chen L, Feng W, Shi $\mathrm{H}, \mathrm{Yu} X$, et al: bFGF attenuates endoplasmic reticulum stress and mitochondrial injury on myocardial ischaemia/reperfusion via activation of PI3K/Akt/ERK1/2 pathway. J Cell Mol Med 19: 595-607, 2015.

27. Chen CM, Wu CT, Yang TH, Chang YA, Sheu ML and Liu SH: Green tea catechin prevents hypoxia/reperfusion-evoked oxidative stress-regulated autophagy-activated apoptosis and cell death in microglial cells. J Agric Food Chem 64: 4078-4085, 2016.

28. Mihaylova MM and Shaw RJ: The AMPK signalling pathway coordinates cell growth, autophagy and metabolism. Nat Cell Biol 13: 1016-1023, 2011.

29. Qi D and Young LH: AMPK: Energy sensor and survival mechanism in the ischemic heart. Trends Endocrinol Metab 26: 422-429, 2015.

30. Hers I, Vincent EE and Tavare JM: Akt signalling in health and disease. Cell Signal 23: 1515-1527, 2011.

31. Manning BD and Cantley LC: AKT/PKB signaling: Navigating downstream. Cell 129: 1261-1274, 2007.

32. Avalos Y, Canales J, Bravo-Sagua R, Criollo A, Lavandero S and Quest AF: Tumor suppression and promotion by autophagy. Biomed Res Int 2014: 603980, 2014.

33. Iurlaro R and Munoz-Pinedo C: Cell death induced by endoplasmic reticulum stress. FEBS J 283: 2640-2652, 2016

34. Saggioro FP, Neder L, Stavale JN, Paixão-Becker ANP, Malheiros SMF, Soares FA, Pittella JEH, Matias CCMS, Colli BO, Carlotti CG Jr and Franco M: Fas, FasL, and cleaved caspases 8 and 3 in glioblastomas: A tissue microarray-based study. Pathol Res Pract 210: 267-273, 2014.

35. Schito L and Semenza GL: Hypoxia-inducible factors: Master regulators of cancer progression. Trends Cancer 2: 758-770, 2016.

36. LaGory EL and Giaccia AJ: The ever-expanding role of HIF in tumour and stromal biology. Nat Cell Biol 18: 356-365, 2016.

37. Kurokawa $\mathrm{M}$ and Kornbluth $\mathrm{S}$ : Caspases and kinases in a death grip. Cell 138: 838-854, 2009.

38. Lange N, Unger FT, Schoppler M, Pursche K, Juhl H and David KA: Identification and validation of a potential marker of tissue quality using gene expression analysis of human colorectal tissue. PLoS One 10: e0133987, 2015. 
39. Pietrocola F, Izzo V, Niso-Santano M, Vacchelli E, Galluzzi L, Maiuri MC and Kroemer G: Regulation of autophagy by stress-responsive transcription factors. Semin Cancer Biol 23: 310-322, 2013.

40. Verzella D, Pescatore A, Capece D, Vecchiotti D, Ursini MV, Franzoso G, Alesse E and Zazzeroni F: Life, death, and autophagy in cancer: NF- $\mathrm{kB}$ turns up everywhere. Cell Death Dis 11: 210, 2020.

41. Karar J and Maity A: PI3K/AKT/mTOR pathway in angiogenesis. Front Mol Neurosci 4: 51, 2011.

42. Nazarko VY and Zhong Q: ULK1 targets beclin-1 in autophagy. Nat Cell Biol 15: 727-728, 2013.

43. Kim SJ, Dix DJ, Thompson KE, Murrell RN, Schmid JE, Gallagher JE and Rockett JC: Effects of storage, RNA extraction, genechip type, and donor sex on gene expression profiling of human whole blood. Clin Chem 53: 1038-1045, 2007.
44. Becker N and Lockwood CM: Pre-analytical variables in miRNA analysis. Clin Biochem 46: 861-868, 2013.

45. Willemse EA and Teunissen CE: Biobanking of cerebrospinal fluid for biomarker analysis in neurological diseases. Adv Exp Med Biol 864: 79-93, 2015.

(7)(9) This work is licensed under a Creative Commons

EY No NO Attribution-NonCommercial-NoDerivatives 4.0 International (CC BY-NC-ND 4.0) License. 